\title{
Pluripotent stem cells and mitochondrial dysfunction
}

\author{
Li-Pin $\mathrm{Kao}^{1,2,3 *}$ and Wolvetang $\mathrm{EJ}^{3}$ \\ ${ }^{1}$ Department of Basic Medical Sciences, Purdue University, West Lafayette, Indiana, USA \\ ${ }^{2}$ Centre for Cancer Research, Purdue University, West Lafayette, Indiana, USA \\ ${ }^{3}$ Australian Institute for Bioengineering and Nanotechnology, The University of Queensland, Brisbane, QLD, Australia
}

\begin{abstract}
Embryonic stem cells (ESCs) are derived from the inner-cell-mass (ICM) of blastocysts. ESC and induced pluripotent stem cell (iPSC) lines are immortal, meaning that they have unlimited proliferation potential. They are also pluripotent; that is, they can differentiate into lineages derived from all 3 major germ layers of the embryo. Consequently, these cells have been widely investigated in the development of regenerative medicine therapies. Human ESCs have been regarded as important research tools for the investigation into early development of the human embryo.

Mitochondria are the powerhouses capable of providing the majority of energy within the cell and performing important metabolic functions such as the Krebs cycle. The well-known endosymbiotic theory [1] has suggested that the mitochondrion was originally derived from a prokaryotic cell that invaded a larger, nucleated host cell. Mitochondria indeed contain their own mitochondrial DNA (mtDNA) in a circular form, similar to the bacterial genome. Mitochondrial genomes encode several essential genes of the eukaryotic respiratory machinery. However, most of the components of the respiratory machinery and factors controlling mitochondrial biogenesis are encoded in the nucleus. The cooperation and communication between mitochondria and nuclei are conducted by retrograde signals, such as energy supply and redox signaling and this currently poorly-understood communication is essential for balancing energy production and demand in the cell. Targeting mitochondria metabolism for inherited disease by using pluripotent stem cells is still a major therapeutic direction for cell therapy.
\end{abstract}

\section{Human pluripotent stem cells}

Stem cells are endowed with a unique capacity for self-renewal [2]. In mammalian development, fertilized oocytes are able to differentiate into all types of cells and are thus classified as totipotent. 'Totipotent' is derived from the Latin totus, which means 'entire'. A totipotent stem cell has the ability to generate all cell types found in the embryo and in extra-embryonic tissues. Fertilized oocytes divide and progress into 8-cell embryos and then blastocysts. Blastocysts are composed of an outer layer of cells, called trophoblasts, and inner cells, which form the inner cell mass (ICM). The ICM can develop into all cell types of the adult body and is therefore called 'pluripotent', a term derived from the Latin plures, meaning 'several' or 'many'. Pluripotent stem cells, such as mouse embryonic stem cells (mESCs), human embryonic stem cells (hESCs), and induced pluripotent stem cells (iPSCs), can differentiate into ectoderm, mesoderm, endoderm, and germ cells [3].

Once blastocyst-derived cells have fully differentiated into tissues or organs, stem cells that reside in various tissues and organs remain in order to generate new tissue or repair damaged tissue. These stem cells, known as multipotent stem cells or adult stem cells (ASCs), include mesenchymal stem (or stromal) cells (MSCs) and hematopoietic stem cells (HSCs). Their differentiation ability is limited compared to that of totipotent and pluripotent cells. For example, hematopoietic stem cells, which are found in bone marrow, can differentiate into erythrocytes and white blood cells (including macrophages). These types of cells are important for homeostasis because they enable the steady self-renewal of tissue.

There are different types of pluripotent stem cells: embryonic stem cells (ESCs), induced pluripotent stem cells (iPSCs), embryonic germ cells (EGCs), and embryonic carcinoma cells (ECCs). ESCs are isolated from the ICM of the blastocyst (Figure 1) [4], whereas iPSCs are artificially generated by reprogramming somatic cells using a defined set of transcription factors. iPSCs are similar to hESCs in morphology, gene expression, and differentiation ability [5]. Human embryonic germ cells (hEGCs) are derived from the primordial germ cells (PGCs) and are pluripotent stem cells [6]. Embryonic carcinoma cells (ECCs)

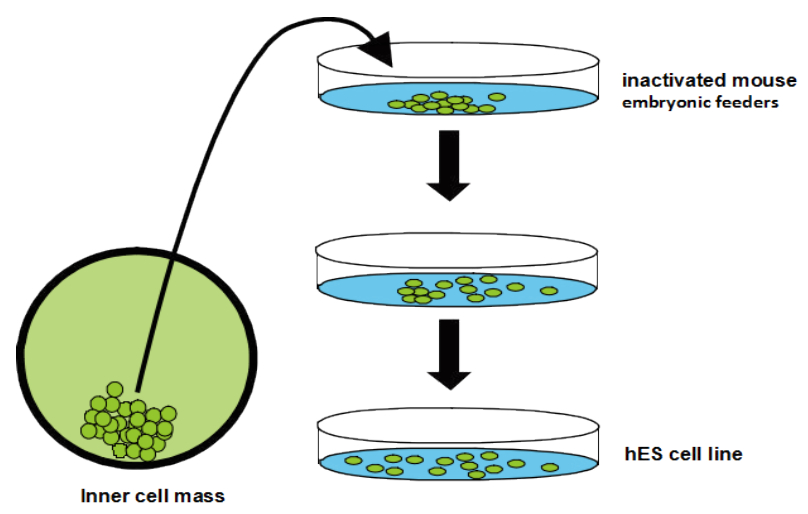

Figure 1. hESC isolation and culture procedures. hESCs are derived from the inner cell mass of the blastocyst (left). For long-term culture, hESCs are grown on inactivated mouse embryonic fibroblasts used as a feeder layer [13].

Correspondence to: Li-Pin Kao, Department of Basic Medical Sciences, Purdue University, West Lafayette, Indiana, USA; Centre for Cancer Research, Purdue University, West Lafayette, Indiana, USA; Australian Institute for Bioengineering and Nanotechnology, The University of Queensland, Brisbane, QLD, Australia, E-mail: kaolipin@gmail.com

Key words: pluripotent stem cells, human embryonic stem cells

Received: October 02, 2017; Accepted: October 16, 2017; Published: October 18 2017 
are stem cells derived from teratocarcinomas, which are tumors that arise from embryonic tissues such as those from the testis or ovary, or from cultures of explanted cells [7]. ECCs are considered the malignant counterparts of hESCs.

\section{Embryonic stem cells (ESCs) and induced pluripotent stem cells (iPSCs)}

Evans and Kaufman (1981) were the first to derive ESCs from an early mouse embryo [8]. In 1998, Thomson and colleagues reported the first successful derivation of hESC lines [9]; these lines are still widely used. They are capable of proliferating extensively in their undifferentiated state in vitro and have the ability to differentiate into all three germ layers $[6,10]$. The embryo-derived hESCs were established from blastocysts discarded during in vitro fertilization (IVF) procedures.

iPSCs are an artificially generated type of pluripotent stem cell. iPSCs are reprogrammed from adult somatic cells to acquire stem cell-like properties through the forced expression of a combination of transcription factors, such as Oct4, Sox2, Nanog, c-myc, KLF4, and Lin28. Takahashi and Yamanaka introduced four pluripotent genesOct4, Sox2, c-myc, and Kruppel-like family transcription factor 4 (Klf4) - that could reprogram mouse fibroblasts into mouse-induced pluripotent stem cells (miESCs) or human fibroblasts into humaninduced pluripotent stem cells (hiPSCs) [11]. Thomson and colleagues used Oct 4 and Sox 2 in combination with Nanog and Lin-28 homolog (Lin28), instead of c-myc and Klf4, to reprogram human fibroblasts into hiPSCs [12]. These iPSCs express stem cell markers and can differentiate into three germ layers in a teratoma in vivo.

iPSCs have the advantage that they do not require the destruction of an embryo. Moreover, given their origin, they provide a perfect match to the cell donor (are fully isogenic) and thus would likely avoid rejection by the donor's immune system.

\section{Characterization of undifferentiated hESCs}

Undifferentiated hESCs express high levels of cell surface antigens that can be used as stem cell-specific pluripotency markers. These antigens include: (1) glycolipids, such as the stage-specific embryonic antigens SSEA-3 and SSEA-4 [14]; (2) glycoproteins, such as TRA1-60 and TRA-1-81 [15]; and (3) alkaline phosphatase [4,16,17]. Pluripotency markers include the transcription factors Octamer-4, POU domain, class 5, transcription factor 1 (OCT4 or POU5F1) [18-20]; sex-determining region Y-box 2 (SOX2) [21]; and Nanog homeobox (NANOG) [22,23].These molecular markers provide a means of identifying pluripotent stem cells, and a decrease in their expression can be used to monitor the onset of differentiation. The molecular mechanisms underlying the self-renewal of hESCs have not been fully elucidated.

\section{Gene expression analysis of hESCs}

Investigating gene expression in various stem cell lines could give important insights into how stem cells control pluripotency and differentiation. A number of studies have measured hESC gene expression to investigate related molecular mechanisms and have reported differential gene expression in different hESC lines. Rao and Stic (2004) reported a 75\% similarity in the microarray profiles of two lines; in a another study, $48 \%$ of the expressed genes were restricted to one or two lines [24]. However, variations in gene expression have been observed in hESC lines derived within the same laboratory
[25] and even in the same hESC lines (38\%) after three passages in different media [26]. Gene expression also changes during spontaneous differentiation [27]. For example, the expression of leukemia inhibitory factor (LIF) and its receptors is low in undifferentiated hESCs, but increases during differentiation. Differential DNA methylation of pluripotency-associated promoters such as NANOG and OCT4/ POU5F1 has been observed in pluripotent and differentiated cells. Understanding gene expression in hESCs will help shed light on the molecular basis of normal differentiation and the abnormal processes that underlie human developmental disorders.

Several external signals that maintain stem cell pluripotency have been characterized. External signals are also thought to play important roles in the regulation of ESC self-renewal and differentiation. For example, the pluripotency of hESCs is maintained by several signaling pathways [28];

\section{- The Fibroblast Growth Factor (FGF) Signaling Pathway}

Exogenous bFGF is an essential factor in a defined hESC culture medium used for the maintenance of undifferentiated hESCs and hiPSCs in vitro. Withdrawal of bFGF induces the downregulation of pluripotency markers and the differentiation of hESCs. This suggests that FGF signaling plays an important role in self-renewal and pluripotency regulation in human ES cells and iPSCs [29,30]

- The Transforming Growth Factor- $\beta$ (TGF- $\beta$ )/Activin/NodalSMAD2/3 Signaling Pathway

The TGF- $\beta$ /Activin/Nodal branch is highly active in undifferentiated hESCs. The pathway supports the self-renewal of undifferentiated hESCs by activating SMAD2/3 and inducing the expression of the pluripotency markers Oct 4 and Nanog [31,32]. The TGF- $\beta$ /Activin/ Nodal-SMAD2/3 signaling pathway is important in maintaining the self-renewal and pluripotency of hESCs [33].

- The Phosphoinositide-3-Kinase (PI3K) Signaling Pathway

The PI3K protein is highly expressed in undifferentiated cells and is downregulated in differentiated ESCs [34,35]. Blocking the PI3K signaling pathway with the PI3K inhibitor LY294002 results in the loss of pluripotency markers and initiates cellular differentiation [36]. In addition, activation of the PI3K signaling pathway induces the PI3Kdependent phosphorylation of $\mathrm{PKB} / \mathrm{Akt}$ and GSK-3 $\alpha / \beta$ proteins.

\section{Propagation of undifferentiated hESCs}

Initially, hESCs were grown on irradiated mouse feeders or human foreskin fibroblasts [37]. However, exposure to animal-derived culture constituents is a drawback of the feeder-dependent systems [38]. Given that hESCs and hiPSCs are attractive candidates for future human cell transplantation, it is important to optimize good manufacturing practice (GMP)-compliant systems for the derivation, scale-up, and banking of cells and their corresponding quality assurance controls $[39,40]$. Therefore feeder-free systems are increasingly used in combination with xeno-free defined culture medium and GMPcompliant coating substrates specially designed for hESC growth [41], including laminin and fibronectin.

\section{Pluripotent stem cell differentiation}

In vitro and in vivo, hES and iPS cells can differentiate into cell types from the three primitive germ layers: ectoderm, mesoderm, and endoderm $[4,6,16]$ (Figure 2). The differentiation capacity of these cells is typically tested by assessing their spontaneous differentiation in cell 
Undifferenitated hESCs
(POU5F1/TRA-1-80/DAPI)

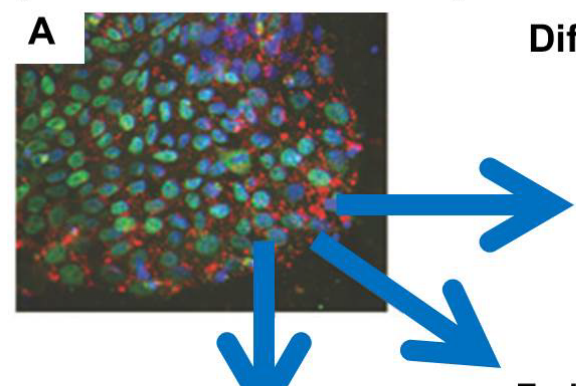

Endoderm:

Mesoderm: Heart, skeletal muscle, kidney, spleen et al. Liver, lungs, pancreas thyroid, epithelial lining of gastrointestinal system, et al.

Ectoderm:

Central nervous system, nerves, mammary glands et al.

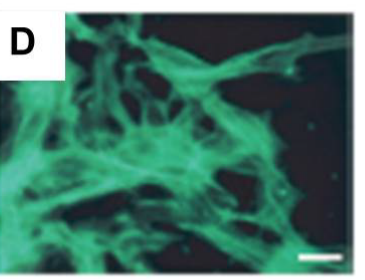

Cardiomyocytes (titin Z-band epitope)

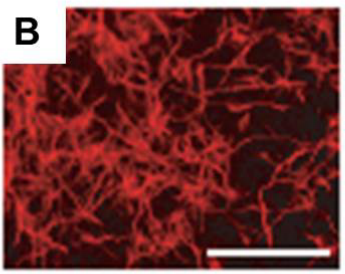

Neurons ( $\beta$ III tubulin)

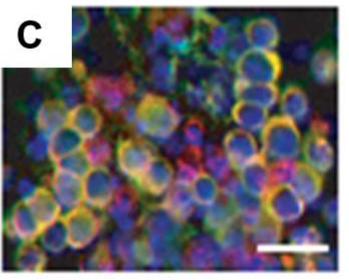

Pancreatic cells (C-peptide/Insulin/DAPI)

Figure 2. Undifferentiated hES cells (A) can give rise to cell types from the three primitive germ layers: (B) neuronal cells in ectoderm-lineage differentiation, (C) pancreatic cells in endoderm-lineage differentiation, and (D) cardiomyocytes in mesoderm-lineage differentiation. This figure is adapted from Hoffman and Carpenter 2005 [13]

culture (i.e. in vitro formation of embryonic bodies or EBs). Upon the removal of growth factor (e.g. bFGF) or feeder layers and/or transfer to suspension conditions, hESCs undergo spontaneous unguided differentiation into various cells representative of the different germ layers. In two-dimensional (2D) spontaneously differentiated hESCs, the different morphologies appeared to be epithelial cells, neural cells with axons and dendrites, and cells with mesenchymal characteristics [42]. In suspension, the hESCs form multicellular aggregates of differentiated and undifferentiated cells called embryoid bodies (EBs), which resemble early post-implantation embryos and frequently progress through a series of differentiation stages [37,43,44]. Typically, EBs are allowed to grow for several days or weeks, with samples taken at intervals for analysis via flow cytometry or immunocytochemical staining. In vitro and in vivo assessments of differentiation involve determining whether the derived cells have acquired a variety of ectoderm-, mesoderm-, and endoderm-like properties (and loss of markers for pluripotency). In vivo assessment of pluripotency is performed by xenografting hESCs and iPSCs into severe combined immune-deficient (SCID) mice and observing the formation of teratomas with derivatives of all three germ layers, which indicates that the injected stem cells have the ability to differentiation along three lineages $[4,16]$.

\section{Directed differentiation}

To direct the differentiation of ESCs towards a particular cell type, such as a neuronal cell type or a cardiomyocyte cell type, hESCs in monolayer culture are exposed to certain growth factors or stimuli and extracellular matrix components, either directly or indirectly through feeder cells [45].

Retinoic acid (RA) induces human embryonic stem cells to differentiate into the ectodermic lineage [46]. RA and its receptors play important roles in the development of the central nervous system by initiating the cellular differentiation of neuronal precursors [47]. Several papers have reported that RA induces neuronal differentiation in neuroblastoma cell lines (SH-SY5Y human dopaminergic neuroblastoma cells) [48,49] and human promyelocytic leukemia HL-60 cells [50]. Further, RA also induces embryonic stem cells to differentiate into neuronal cells $[46,51,52]$, including neurons and glial cells. In order to improve the efficiency and reproducibility of neuronal differentiation, several studies have attempted to add small molecules. For example, Idelson $\mathrm{M}$, et al. have demonstrated that nicotinamide promotes the differentiation of hESCs into neural cells and subsequently into retinal pigment epithelium (RPE) cells [53]. Moreover, Lu SJ, et al. have described a robust system that efficiently generates large numbers of hemangioblasts from multiple hESC lines and produces functional homogeneous RBCs with oxygen-carrying capacity on a large scale [54]. The markers of early ectodermdifferentiation are paired box gene 6 (PAX6), SRY (sex determining region Y)-box 1 (SOX1), nesting, and glial fibrillary acidic protein (GFAP). Briggs JA, et al. have demonstrated successful neuronal differentiation via a sophisticated protocol [55].

Mesoderm differentiation has been extensively studied, particularly the families of protein growth factors that control the early stages of mesoderm formation in cardiomyocytes [56]. Hudson J, et al. have used small molecules to target the wingless/INT (Wnt) signaling 
pathway in order to induce the differentiation of hESCs into beating cardiomyocytes [57]. Biomarkers for early mesoderm-differentiation include T-box factor Brachyury (BRY or T), the homeodomain protein MIXL1, and myosin [57]

Endoderm differentiation forms several tissues, including the liver, lung, thyroid, and foregut endoderm. The families of protein growth factors that control the early stage of endoderm differentiation into the anterior-ventral domain of the foregut endoderm are targeted by signaling through Nodal, a member of the transforming growth factor-B (TGF-B) superfamily and the SMAD signaling pathway [58]. The biomarkers of early endoderm differentiation are insulinlike growth factor 2 (IGF2) and gata binding factor (GATA4); SRY (sex determining region Y)-box 17 (SOX17) is also an indicator of the definitive foregut endoderm (Kanai-Azuma, Kanai, et al. 2002, Nakanishi, Kurisaki, et al. 2009). Little is known about the expression of mitochondrial biogenesis-related genes during hESC lineage-specific differentiation.

\section{Mitochondrial dysfunction}

The symptoms of mitochondrial dysfunction caused by mutations or deletions in the mitochondrial genome or by mitochondrial depletion can be observed in whole animals and cellular models. Several studies have described mice with abnormal mitochondria resulting from mutations or deletions in the mitochondrial genome. To demonstrate the importance of mitochondrial morphology and function in cellspecific functions, we have established the mitochondria-depleted cells called rho-zero cells $\left(\rho^{\circ}\right)$, which are depleted of mtDNA, were generated in vitro through the application of different drugs, such as ethidium bromide, antibiotics [59], or the nucleoside analogue reverse transcriptase inhibitor (NARTI, an anti-HIV drug). $\rho^{\circ}$ cells exhibit several common features: (1) they become autotrophic, relying on pyrimidine (uridine) and pyruvate supplementation for cell growth [60,61]; (2) they have a low mtDNA copy number and low expression of mitochondrial-encoded genes, but not of nuclear-encoded genes; (3) they have low mitochondrial respiratory chain complex activities, with the exception of complex II; (4) they have low ATP concentrations, respiration rates (oxygen consumption), and mitochondrial membrane potential; (5) they shift from aerobic to anaerobic metabolism if given supplemental pyruvate; and (6) they have an immature mitochondrial structure with reduced numbers of cristae membranes, circular morphology, and loss of tubular structure.

Upon a reduction in oxygen consumption, several studies have found that antioxidants can reverse the increased ROS production in $\rho^{\circ}$ cells. In addition, $\rho^{\circ}$ cells have decreased levels of cell proliferation, mitotic cyclin gene expression, cyclin-dependent kinase inhibitors, retinoblastoma 1 phosphorylation, and telomerase activity $[62,63]$. In $\rho^{\circ}$ cells, upregulation of mitochondrial biogenesis-related genes, relative to expression in control cells, has been observed [64,65].

Interestingly, it has been suggested that $\rho^{\circ}$ cells have increased resistance to apoptosis. However, they exhibit a normal distribution of cytochrome $\mathrm{c}$ within mitochondria during staurosporine-induced apoptosis (in spite of low mtDNA levels and respiratory function deficiencies). Consistently, caspase 3 activation and DNA fragmentation are not affected in $\rho^{\circ}$ cells. However, the localization of NF- $\kappa B$ is altered (i.e. more NF- $\kappa B$ in the nucleus than in the cytoplasm), which might be related to the observed resistance to apoptosis. Moreover, in $\rho^{\circ}$ cells, a greater amount of mass is associated with lysosome and peroxidation production [65-67]. Remarkably, the differentiation of SH-SY5Y neuroblastoma cells into neuron-like cells is not affected by defective mitochondria, as indicated by the presence of long neurites and secretory granules, which are typical of differentiating neuroblastoma cells [68]. Therefore, targeting mitochondria metabolism or mutations in mitochondrial-related genes for inherited disease by using pluripotent stem cells is still a major therapeutic direction for cell therapy.

\section{Disclosure of potential conflicts of interest}

The authors indicate no potential conflict of interest.

\section{Authorship contribution}

This work was supported by authorship contribution. Wrote or contributed to the writing of the manuscript: Kao and Wolvetang.

\section{Acknowledgment}

The authors would like to acknowledge the financial support of the Australian Postgraduate Award and the support of the Australian Stem Cell Centre's Core hESC Laboratories (Stem Core) for providing cell culture and support services and Purdue University provided support in the form of salaries for KLP listed, but did not have any additional role in the study design, data collection and analysis, decision to publish, or preparation of the manuscript.

\section{References}

1. Martin W, Hoffmeister M, Rotte C, Henze K (2001) An overview of endosymbiotic models for the origins of eukaryotes, their ATP-producing organelles (mitochondria and hydrogenosomes), and their heterotrophic lifestyle. Biol Chem 382: 1521-1539. [Crossref]

2. Weissman IL (2000) Stem cells: units of development, units of regeneration, and units in evolution. Cell 100: 157-168. [Crossref]

3. Lemoli RM, Bertolini F, Cancedda R, De Luca M, Del Santo A, et al. (2005) Stem cell plasticity: time for a reappraisal? Haematologica 90: 360-381. [Crossref]

4. Thomson JA, Itskovitz-Eldor J, Shapiro SS, Waknitz MA, Swiergiel JJ, et al. (1998) Embryonic stem cell lines derived from human blastocysts. Science 282: 1145-1147. [Crossref]

5. Chen G, Gulbranson DR, Hou Z, Bolin JM, Ruotti V, et al. (2011) Chemically defined conditions for human iPSC derivation and culture. Nat Methods 8: 424-429. [Crossref]

6. Thomson JA, Odorico JS (2000) Human embryonic stem cell and embryonic germ cell lines. Trends Biotechnol 18: 53-57. [Crossref]

7. Przyborski SA, Christie VB, Hayman MW, Stewart R, Horrocks GM (2004) Human embryonal carcinoma stem cells: models of embryonic development in humans. Stem Cells Dev 13: 400-408. [Crossref]

8. Evans MJ, Kaufman MH (1981) Establishment in culture of pluripotential cells from mouse embryos. Nature 292: 154-156. [Crossref]

9. Norrman K, Fischer Y, Bonnamy B, Wolfhagen Sand F, Ravassard P, et al. (2010) Quantitative comparison of constitutive promoters in human ES cells. PLoS One 5 e12413. [Crossref]

10. Shamblott MJ, Axelman J, Wang S, Bugg EM, Littlefield JW, et al. (1998) Derivation of pluripotent stem cells from cultured human primordial germ cells. Proc Natl Acad Sci U S A 95: 13726-13731. [Crossref]

11. Takahashi K, Yamanaka S (2006) Induction of pluripotent stem cells from mouse embryonic and adult fibroblast cultures by defined factors. Cell 126: 663-676. [Crossref]

12. Yu J, Vodyanik MA, Smuga-Otto K, Antosiewicz-Bourget J, Frane JL, et al. (2007) Induced pluripotent stem cell lines derived from human somatic cells. Science 318: 1917-1920. [Crossref]

13. Hoffman LM, Carpenter MK (2005) Characterization and culture of human embryonic stem cells. Nat Biotechnol 23: 699-708. [Crossref]

14. Kannagi R 91983) Stage-specific embryonic antigens (SSEA-3 and -4) are epitopes of a unique globo-series ganglioside isolated from human teratocarcinoma cells. The EMBO J 2: 2355-2361 
15. Badcock G, Pigott C, Goepel J, Andrews PW (1999) The human embryonal carcinoma marker antigen TRA-1-60 is a sialylated keratan sulfate proteoglycan. Cancer Res 59: 4715-4719. [Crossref]

16. Reubinoff BE, Pera MF, Fong CY, Trounson A, Bongso A (2000) Embryonic stem cell lines from human blastocysts: somatic differentiation in vitro. Nature biotechnology 18: 399-404.

17. Henderson JK, Draper JS, Baillie HS, Fishel S, Thomson JA, et al. (2002) Preimplantation human embryos and embryonic stem cells show comparable expression of stage-specific embryonic antigens. Stem cells 20: 329-337. [Crossref]

18. Mitsui K, Tokuzawa Y, Itoh H, Segawa K, Murakami M, et al. (2003) The homeoprotein Nanog is required for maintenance of pluripotency in mouse epiblast and ES cells. Cell 113: 631-642. [Crossref]

19. Sperger JM, Chen X, Draper JS, Antosiewicz JE, Chon CH, et al. (2003) Gene expression patterns in human embryonic stem cells and human pluripotent germ cell tumors. Proc Natl Acad Sci U S A 100: 13350-13355. [Crossref]

20. Zangrossi S, Marabese M, Broggini M, Giordano R, D’Erasmo M, et al. (2007) Oct-4 expression in adult human differentiated cells challenges its role as a pure stem cell marker. Stem cells 25: 1675-1680. [Crossref]

21. Avilion AA, Nicolis SK, Pevny LH, Perez L, Vivian N, Lovell-Badge R (2003) Multipotent cell lineages in early mouse development depend on SOX2 function. Genes Dev 17: 126-140. [Crossref]

22. Ivanova NB, Dimos JT, Schaniel C, Hackney JA, Moore KA, et al. (2002) A stem cell molecular signature. Science 298: 601-604. [Crossref]

23. Pan G, Thomson JA (2007) Nanog and transcriptional networks in embryonic stem cell pluripotency. Cell Res 17: 42-49. [Crossref]

24. Abeyta MJ, Clark AT, Rodriguez RT, Bodnar MS, Pera RA, Firpo MT (2004) Unique gene expression signatures of independently-derived human embryonic stem cell lines. Hum Mol Genet 13: 601-608. [Crossref]

25. Ginis I, Luo Y, Miura T, Thies S, Brandenberger R, et al. (2004) Differences between human and mouse embryonic stem cells. Dev Biol 269: 360-380. [Crossref]

26. Rao RR (2004) Comparative transcriptional profiling of two human embryonic stem cell lines. Biotechnology and bioengineering 88: 273-286.

27. Aghajanova L, Skottman H, Strömberg AM, Inzunza J, Lahesmaa R, Hovatta O (2006) Expression of leukemia inhibitory factor and its receptors is increased during differentiation of human embryonic stem cells. Fertil Steril 86: 1193-1209. [Crossref]

28. Ohtsuka S, Dalton S (2008) Molecular and biological properties of pluripoten embryonic stem cells. Gene Ther 15: 74-81. [Crossref]

29. Eisenberg T, Knauer H, Schauer A, Büttner S, Ruckenstuhl C, et al. (2009) Induction of autophagy by spermidine promotes longevity. Nat Cell Biol 11: 1305-1314. [Crossref]

30. Xu RH, Peck RM, Li DS, Feng X, Ludwig T, Thomson JA (2005) Basic FGF and suppression of BMP signaling sustain undifferentiated proliferation of human ES cells. Nat methods 2: 185-190. [Crossref]

31. James D, Levine AJ, Besser D, Hemmati-Brivanlou A (2005) TGFbeta/activin/noda signaling is necessary for the maintenance of pluripotency in human embryonic stem cells. Development 132: 1273-1282. [Crossref]

32. Vallier L, Alexander M, Pedersen RA (2005) Activin/Nodal and FGF pathways cooperate to maintain pluripotency of human embryonic stem cells. J cell Sci 118: 4495-4509. [Crossref]

33. Valdimarsdottir G, Mummery C (2005) Functions of the TGFbeta superfamily in human embryonic stem cells. APMIS: acta pathologica, microbiologica, et immunologica Scandinavica, 113: 773-789.

34. Armstrong L, Hughes O, Yung S, Hyslop L, Stewart R, Wappler I, et al. (2006) The role of PI3K/AKT, MAPK/ERK and NFkappabeta signalling in the maintenance of human embryonic stem cell pluripotency and viability highlighted by transcriptional profiling and functional analysis. Hum Mol Genet 15: 1894-1913. [Crossref]

35. Di Cristofano A, Pesce B, Cordon-Cardo C, Pandolfi PP (1998) Pten is essential for embryonic development and tumour suppression. Nat Genet 19: 348-355. [Crossref]

36. Paling NR, Wheadon H, Bone HK, Welham MJ (2004) Regulation of embryonic stem cell self-renewal by phosphoinositide 3-kinase-dependent signaling. J Biol Chem 279: 48063-48070. [Crossref]

37. Inzunza J, Gertow K, Strömberg MA, Matilainen E, Blennow E, et al. (2005) Derivation of human embryonic stem cell lines in serum replacement medium using postnatal human fibroblasts as feeder cells. Stem cells 23: 544-549. [Crossref]
38. Sidhu KS, Walke S, Tuch BE (2008) Derivation and propagation of hESC under a therapeutic environment. Curr Protoc Stem Cell Biol Chapter 1: Unit 1A. [Crossref]

39. Ausubel LJ, Lopez PM, Couture LA (2011) GMP scale-up and banking of pluripotent stem cells for cellular therapy applications. Methods Mol Biol 767: 147-159. [Crossref]

40. Unger C, Skottman H, Blomberg P, Dilber MS, Hovatta O (2008) Good manufacturing practice and clinical-grade human embryonic stem cell lines. Hum Mol Genet 17: R4853. [Crossref]

41. Yoon TM, Chang B, Kim HT, Jee JH, Kim DW, Hwang DY (2010) Human embryonic stem cells (hESCs) cultured under distinctive feeder-free culture conditions display global gene expression patterns similar to hESCs from feeder-dependent culture conditions. Stem Cell Rev 6: 425-437. [Crossref]

42. Odorico JS, Kaufman DS, Thomson JA (2001) Multilineage differentiation from human embryonic stem cell lines. Stem cells 19: 193-204. [Crossref]

43. Chen BZ, Yu SL, Singh S, Kao LP, Tsai ZY, et al. (2011) Identification of microRNAs expressed highly in pancreatic islet-like cell clusters differentiated from human embryonic stem cells. Cell Biol Int 35: 29-37. [Crossref]

44. Li SS, Yu SL, Kao LP, Tsai ZY, Singh S, et al. (2009) Target identification of microRNAs expressed highly in human embryonic stem cells. J Cell Biochem 106 1020-1030. [Crossref]

45. Schuldiner M, Yanuka O, Itskovitz-Eldor J, Melton DA, Benvenisty N (2000) Effect of eight growth factors on the differentiation of cells derived from human embryonic stem cells. Proc Natl Acad Sci U S A 97: 11307-11312. [Crossref]

46. Guan K, Chang H, Rolletschek A, Wobus AM (2001) Embryonic stem cell-derived neurogenesis. Retinoic acid induction and lineage selection of neuronal cells. Cell Tissue Res 305: 171-176. [Crossref]

47. Niederreither K, Dollé P (2008) Retinoic acid in development: towards an integrated view. Nat Rev Genet 9: 541-553. [Crossref]

48. Constantinescu R, Constantinescu AT, Reichmann H, Janetzky B (2007) Neuronal differentiation and long-term culture of the human neuroblastoma line SH-SY5Y. $J$ Neural Transm Suppl 17-28. [Crossref]

49. Lopes FM, Schröder R, da Frota ML Jr, Zanotto-Filho A, Müller CB, et al. (2010) Comparison between proliferative and neuron-like SH-SY5Y cells as an in vitro model for Parkinson disease studies. Brain Res 1337: 85-94. [Crossref]

50. Racanicchi L, Montanucci P, Basta GP, Pensato A, Conti V, Calafiore R (2008) Effect of all trans retinoic acid on lysosomal alpha-D-mannosidase activity in HL-60 cell: correlation with HL-60 cells differentiation. Mol Cell Biochem 308: 17-24. [Crossref]

51. Liu L, Liu C, Zhong Y, Apostolou A, Fang S (2012) ER stress response during the differentiation of $\mathrm{H} 9$ cells induced by retinoic acid. Biochem Biophys Res Commun 417: 738-743. [Crossref]

52. Parsons XH (2011) Efficient derivation of human neuronal progenitors and neurons from pluripotent human embryonic stem cells with small molecule induction. $J$ Vis Exp e3273. [Crossref]

53. Idelson M, Alper R, Obolensky A, Ben-Shushan E, Hemo I, et al. (2009) Directed differentiation of human embryonic stem cells into functional retinal pigment epithelium cells. Cell stem cell 5: 396-408. [Crossref]

54. Lu SJ, Feng Q, Park JS, Lanza R (2010) Directed differentiation of red blood cells from human embryonic stem cells. Methods Mol Biol636: 105-121. [Crossref]

55. Briggs JA, Sun J, Shepherd J, Ovchinnikov DA, Chung TL, et al. (2013) Integrationfree induced pluripotent stem cells model genetic and neural developmental features of down syndrome etiology. Stem Cells 31: 467-478. [Crossref]

56. Mummery CL, Zhang J, Ng ES, Elliott DA, Elefanty AG, Kamp TJ (2012) Differentiation of human embryonic stem cells and induced pluripotent stem cells to cardiomyocytes: a methods overview. Circ Res 111: 344-358. [Crossref]

57. Hudson J, Titmarsh D, Hidalgo A, Wolvetang E, Cooper-White J (2012) Primitive cardiac cells from human embryonic stem cells. Stem Cells Dev 21: 1513-1523. [Crossref]

58. Kim SW, Yoon SJ, Chuong E, Oyolu C, Wills AE, et al. (2011) Chromatin and transcriptional signatures for Nodal signaling during endoderm formation in hESCs. Dev Biol 357: 492-504. [Crossref]

59. Kao LP, Ovchinnikov D, Wolvetang E (2012) The effect of ethidium bromide and chloramphenicol on mitochondrial biogenesis in primary human fibroblasts. Toxicol Appl Pharmacol 261: 42-49. [Crossref]

60. Armand R, Channon JY, Kintner J, White KA, Miselis KA, et al. (2004) The effects of ethidium bromide induced loss of mitochondrial DNA on mitochondrial phenotype and ultrastructure in a human leukemia T-cell line (MOLT-4 cells). Toxicol App Pharmacol 196: 68-79. [Crossref] 
61. Miceli MV, Jazwinski SM (2005) Nuclear gene expression changes due to mitochondrial dysfunction in ARPE-19 cells: implications for age-related macular degeneration. Invest Ophthalmol Vis Sci 46: 1765-1773. [Crossref]

62. Park SY, Choi B, Cheon H, Pak YK, Kulawiec M, et al. (2004) Cellular aging of mitochondrial DNA-depleted cells. Biochemical and biophysical research communications 325: 1399-1405.

63. Schroeder P, Gremmel T, Berneburg M, Krutmann J (2008) Partial depletion of mitochondrial DNA from human skin fibroblasts induces a gene expression profile reminiscent of photoaged skin. J Invest Dermatol 128: 2297-2303. [Crossref]

64. Joseph AM, Rungi AA, Robinson BH, Hood DA (2004) Compensatory responses of protein import and transcription factor expression in mitochondrial DNA defects. $\mathrm{Am} \mathrm{J}$ Physiol Cell Physiol 286: C867-875. [Crossref]
65. Miranda S, Foncea R, Guerrero J, Leighton F (1999) Oxidative stress and upregulation of mitochondrial biogenesis genes in mitochondrial DNA-depleted HeLa cells. Biochem Biophys Res Commun 258: 44-49. [Crossref]

66. Appleby RD, Porteous WK, Hughes G, James AM, Shannon D, et al. (1999) Quantitation and origin of the mitochondrial membrane potential in human cells lacking mitochondrial DNA. Eur J Biochem 262: 108-116. [Crossref]

67. King MP, Attardi G (1989) Human cells lacking mtDNA: repopulation with exogenous mitochondria by complementation. Science 246: 500-503. [Crossref]

68. Miller SW, Trimmer PA, Parker WD Jr, Davis RE (1996) Creation and characterization of mitochondrial DNA-depleted cell lines with "neuronal-like" properties. J Neurochem 67: 1897-1907. [Crossref]

Copyright: $₫ 2017$ Kao LP. This is an open-access article distributed under the terms of the Creative Commons Attribution License, which permits unrestricted use, distribution, and reproduction in any medium, provided the original author and source are credited. 